\title{
Hajléktalan emberek foglalkoztatásának elősegítése
}

\section{Promoting the Employment of Homeless People}

\section{ÖsSZEFOGLALÁS}

A koronavírus-járvány okozta válság komoly kihívások elé állította a munkáltatókat és a munkavállalókat egyaránt. Különösen nehéz helyzetbe kerültek a hátrányos helyzetű munkavállalók. Tanulmányomban kiemelten a hajléktalan emberek foglalkozatásáról írok. Először ismertetem a 2020-as év magyar munkaerőpiaci folyamatait. Majd bemutatom a munkaerőpiaci szempontból hátrányos helyzetű csoportokat. Ezt követően a hajléktalan emberek csoportjával foglalkozom. Kifejtem a koronavírus válság hatását a hajléktalan emberek foglalkoztatására. Megvizsgálom a hátrányos helyzet és a felnőttképzés kapcsolatát. Ismertetem az alacsony végzettségűek csoportját. Foglalkozom a felnőttképzés lehetőségeivel a hátrányok csökkentésében, továbbá az egész életen át tartó tanulással. Kifejtem a kompetencia, kompetenciamenedzsment fogalmát. Helyzetelemzést készítek és megfogalmazom a problémát, feltárom annak lehetséges okait. Végül bemutatom azt a két fô modellt, amelyek célja a tartósan közterületeken élő, összetett szükségletű hajléktalan emberek hatékony kigondozása.
Journal of Economic Literature (JEL) kódok: B55, E24, J64

Kulcsszavak: szociális biztonság, támogatási rendszer, közszolgálat

\section{SUMMARY}

The coronavirus crisis has posed serious challenges to employers and employees alike. Disadvantaged employees found themselves in a particularly difficult situation. My study focuses on the employment of homeless people. First, I describe the Hungarian labour market developments in 2020. Then, I present the groups that are disadvantaged in the labour market. After that, I focus on the group of homeless people. I explain the impact of the coronavirus crisis on the employment of homeless people. I examine the relationship between the disadvantaged situation and adult education. I describe the lowqualified group of workers. I discuss the potential of adult learning to reduce disadvantages and lifelong learning. I explain the concepts of competency and competency management. I carry out a situation analysis and formulate the

VÁGner ViviEn, PhD hallgató, Pannon Egyetem (vagner.vivien@gtk.unipannon.hu). 
problem, exploring its possible causes. Finally, I present two main models for the effective care of homeless people with complex needs living permanently in public spaces.

Journal of Economic Literature (JEL) codes: B55, E24, J64

Keywords: homelessness, employment, competencies

\section{A 2020-AS ÉV MUNKAERŐPIACI FOLYAMATAI MagyarorszáGON}

A 2020-as év első hónapjaiban megjelent és gyors ütemben terjedni kezdett Európában a koronavírus okozta betegség, ami Magyarországon március hónapban jelentkezett. A vírus terjedése elleni védekezés érdekében bevezetett intézkedések jelentősen befolyásolták a munkaerőpiaci folyamatokat. 2020 első félévében a foglalkoztatottak átlagos létszáma a 15-74 éves népességben 4 millió 437 ezer fö volt, 67 ezerrel fővel kevesebb, mint az előző év azonos időszakában (KSH adatok alapján).

A megváltozott helyzetre a munkáltatók eltérő válaszokat adtak. 2020 II. negyedévében a munkáltatók egy része átmenetileg szüneteltette a tevékenységét a dolgozóik munkaviszonyának fenntartása mellett, ez több mint 73 ezer munkavállalót érintett. Sok szülő kénytelen volt szüneteltetni a munkavégzést a digitális oktatásra való átállás, valamint az óvodák, bölcsődék bezárása miatt. Sokan fizetett vagy fizetés nélküli szabadságra mentek, a szabadságon és a betegszabadságon lévők száma duplája volt az előző év azonos időszakaihoz képest.

A munkától való kényszerű távolmaradás következményeként jelentősen csökkent a ledolgozott munkaórák száma. Áprilisban 9,5 órával csökkent a heti ledolgozott munkaórák száma. A munkával töltött idő drasztikusan lecsökkent a szálláshely-szolgáltatás, vendéglátás, feldolgozóipar, művészet, szórakoztatás, szabadidő, szépségápolást és fizikai közérzetet javító szolgáltatásokat magába foglaló egyéb szolgáltatás ágazatokban (ksh.hu).

A munkanélküliek átlagos száma 2020 I. félévében 194 ezer fó, a munkanélküliségi ráta 4,2\% volt. A munkanélküliek száma 33,3 ezer fôvel, a munkanélküliségi ráta 0,7 százalékponttal nőtt az előző év azonos időszakához képest (ksh.hu).

\section{1. ábra A foglalkoztatottakon belül azok aránya, akik a referenciahéten nem dolgoztak}

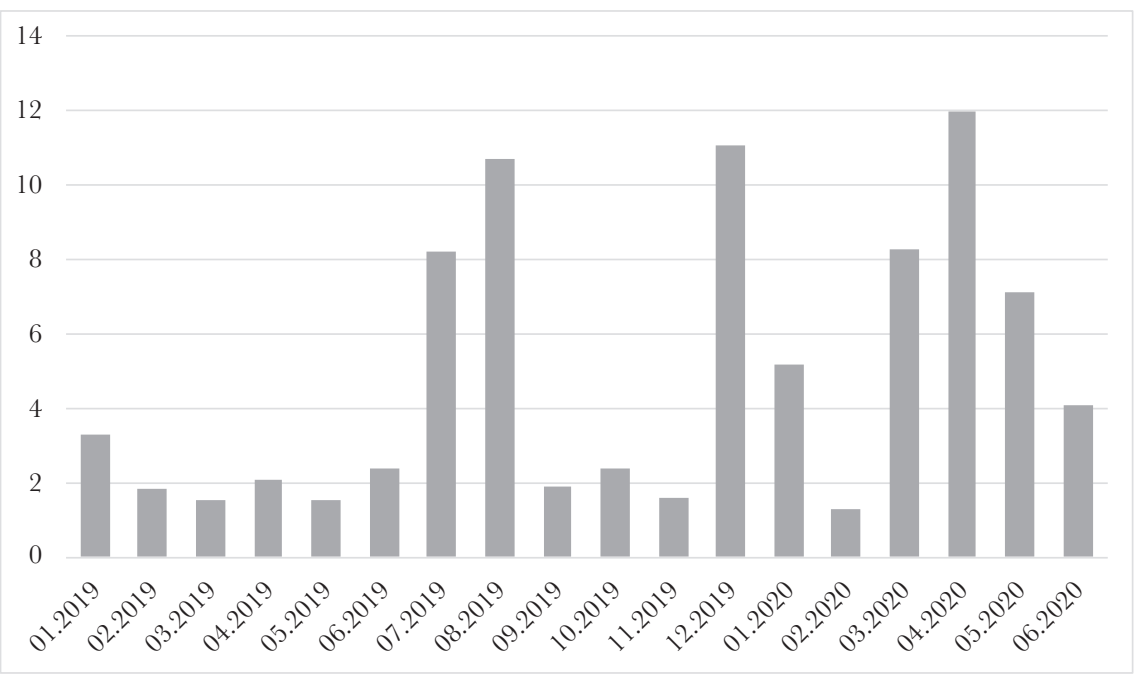

Forrás: KSH Munkaeröpiaci folyamatok, 2020. I. félév 
MUNKAERŐ-PIAGI SZEMPONTBÓL HÁTRÁNYOS HELYZETÜ CSOPORTOK

A hátrányos helyzet egy relatív fogalom, így a definíciója sokféle és összetett. Foglalkoztatáspolitikai szempontból hátrányos helyzetű az, akinek a munkaerő-piaci esélyei az átlagnál alacsonyabbak. A támogatások megállapításának szempontjából hátrányos helyzetű személynek tekintik azt, aki:

- legfeljebb alapfokú iskolai végzettséggel rendelkezik, vagy

- a foglalkoztatás megkezdésekor az ötvenedik életévét betöltötte, vagy

- 25. életévét be nem töltött pályakezdő álláskereső, vagy

- a foglalkoztatás megkezdését megelőző 16 hónap alatt legalább 12 hónapig, 25. életévét be nem töltött pályakezdő álláskeresőnek nem tekinthető személy esetében 8 hónap során 6 hónapig álláskeresőként volt nyilvántartva vagy,

- a saját háztartásában legalább egy 18 évesnél fiatalabb gyermeket egyedül nevel vagy,

- a foglalkoztatás megkezdését megelőző 12 hónapon belül gyermekgondozási segélyben, gyermeknevelési támogatásban, illetőleg terhességi gyermekágyi segélyben, gyermekgondozási díjban vagy ápolási díjban részesült, vagy

- a foglalkoztatás megkezdését megelőző 12 hónapon belül előzetes letartóztatásban volt, szabadságvesztés, vagy elzárás büntetését töltötte (Nagy, 2011).

\section{Hátrányos helyzet kialakulásának az okai}

A hátrányos helyzet kialakulásának léteznek társadalmi és egyénhez kötődő okai. A legfontosabb társadalmi okok az alábbiak:

- földrajzi adottságok: lakhely típusa, közlekedési lehetőségek;

- gazdasági körülmények: „mélyszegénység", munkanélküliség, hajléktalanság; nyelvi és kulturális háttér: nemzetiségek, menekültek.
Számos egyénhez kötődő ok is ismeretes, mint pl. kor, nem, vagy a képzettség, amely az ismerethiány, a kommunikációs és szocializációs problémákon keresztül okozhat problémákat. De ide sorolható még:

- a szegénység;

- a szexuális irányultság;

- a testi, érzékszervi, szellemi fogyatékosság;

- a mentális- és pszichés problémák;

- a káros szenvedélyek - drog, alkohol, dohányzás, játék-szenvedély (Alliquander, 2013).

\section{HajléKTALAN EMBEREK CSOPORTJA}

A hajléktalanságnak sok megközelítési módja létezik. A probléma értelmezhető jogi, munkaerő-piaci, iskolázottsági, közgazdasági, lakásügyi, pszichiátriai, fejlődéstani és egyéb szempontokból (Breitner, 1999).

Magyarországon sokféle statisztika létezik a hajléktalan emberek számáról. A legtöbb esetben a hajléktalanellátó-rendszerben található férőhelyek számát veszik alapul. A Menhely Alapítvány és a Medián Közvélemény- és Piackutató Intézet felmérte a lakosság hajléktalan emberekkel kapcsolatos attitűdjét. A kutatás során kiderült, hogy hány embernek volt a megkérdezéskor közvetlen tapasztalata a hajléktalansággal. Az eredmények azt mutatták, hogy a felnőtt korú lakosság 7\%-ának van olyan ismerőse, rokona, vagy családtagja, aki hajléktalan. Ezek szerint több mint 600.000 embernek közvetlen tapasztalatai vannak erről az élethelyzetről (Győri, 2021).

Koronavírus- járvány okozta válság hatása a hajléktalan emberek foglalkoztatására

A „Február Harmadika” kutatást a szociális ellátó rendszerben dolgozó szakemberek 1998 óta minden évben az „év leghidegebb napján” végezik el. A Február Harmadika munkacsoport szakértőinek becslése szerint egy téli napon 14.000 ember van hajléktalan helyzetben Magyarországon, közülük 10.000 ember va- 
lamilyen hajléktalan szálláson, 4.000 ember közterületen alszik. 2021-ben 1500 közterületen élő és 5200 hajléktalan szállón élő ember válaszolt az országos adatfelvétel kérdéseire.

A járvány következtében a munkaképes korban lévő hajléktalan emberek 42\%-ának csökkent a jövedelme, közel minden második dolgozó hajléktalan ember elveszítette a munkáját, másfél-kétszeresére nőtt a semmiféle jövedelemmel nem rendelkezők aránya. Ezen változások a válaszadók 20-30\%-ánál az alapvető szükségletek kielégítését (táplálkozás, öltözködés, gyógyszerek beszerzése) is folyamatosan korlátozza. A válság a hajléktalan emberek mentális állapotára is hatást gyakorolt (szorongás, félelem, ritkuló emberi kapcsolatok), a hajléktalan emberek többsége kilátástalanul tekint a jövőbe (Győri,2021).

\section{FELNÖTTKÉPZÉS A HÁTRÁNYOS HELYZETÜ} MUNKAVÁLLALÓK ESETÉBEN

\section{Alacsony végzettségüek csoportja}

A hátrányos helyzetűek csoportján belül a legnépesebb csoportot az úgynevezett alacsony végzettségűek alkotják (Nagy, 2011). Alacsony végzettségűeknek azokat a személyeket nevezik, akik a munkaerőpiac szempontjából a minimumszintet sem érik el az iskolázottság területén. Ide sorolják a 8 osztályos általános iskolát be nem fejezetteket, és azokat, akik ugyan befejezték alapfokú tanulmányaikat, de más szakképesítést nem szereztek (Andorka, 2003). $\mathrm{Az}$ alacsony végzettségűek csoportját háromféleképpen definiálja a szakirodalom, abszolút, relatív és nemzetközi mércével mérten alacsony végzettségűek.

\section{Abszolút csoport}

Azok a munkaerő-piaci személyek tartoznak az abszolút csoportba, akik az iskolai végzettség tekintetében egy meghatározott minimumszintet sem érnek el. Nincs értelme végzettségi szintjüket valamihez viszonyítva vizsgálni, olyan alacsony végzettséggel ren- delkeznek. Ebbe a csoportba sorolhatók azok, akik a nyolc osztályt nem végezték el, illetve azok is, akik elvégezték az általános iskolát, de egyéb szakképesítéssel nem rendelkeznek (Ciserné, 2006).

\section{Relatív csoport}

A relatíve alacsony végzettségűek definiálása az iskolai erőforrások társadalmon belüli eloszlását vizsgálja, s ennek bizonyos hányadát (pl. alsó kvantilis) tekinti „iskolai szegénynek” (Öry, 2005).

\section{Nemzetközi mércével mérten alacsony végzettségüek csoportja}

A globalizációnak köszönhetően a végzettségi szint nemzetközi viszonylatban való mérésének súlya fokozatosan nő. A végzettségi szint nemzetközi viszonylatban való mérésének súlya egyrészt a globalizációs, másrészt az EU munkaerőpiacának teljes megnyitása irányába vezető folyamatokat tekintve fokozatosan nő. A munkavállalók versenyképességének fokozása az egyre nyíltabb munkaerőpiacon elengedhetetlen, hiszen az a végzettség, ami hazánkban elegendőnek bizonyulhat, lehet, hogy nemzetközi szinten nem versenyképes, vagy fordítva. Az alacsony végzettségúek e szempont szerinti definiálása tehát az alacsony végzettséget a világ és az $\mathrm{EU}$ végzettségi szintjének viszonylatában határozza meg (Öry, 2005:26).

Amennyiben konkrétan meg akarjuk nevezni az alacsony végzettségűeknek nevezett csoport tagjait, akkor a fenti definíció-lehetőségeket összefoglalva megállapíthatjuk, hogy alacsony végzettségűeknek tekinthetjük egyrészt azokat, akik még az általános iskolát sem fejezték be, másrészt a munkaerőpiac szereplőinek azon tagjait, akik ugyan elvégezték az általános iskolát, ugyanakkor ezen kívül semmilyen végzettséget nem szereztek, azaz szakma nélkül szintén kevés esélyük van az elhelyezkedésre (Cserné, 2006:20). 


\section{A hátrányos helyzet és a felnóttképzés kapcsolata}

A hátrányos helyzetű munkavállalók munkaerőpiaci esélyeit ronthatja, hogy egyes csoportoknak közvetlen vetélytársává vált a technikai és technológiai innovációk köre. A modern eszközökhöz kapcsolódó tudás az alapelvárások közé emelkedett. A kiélezett versenyben már az élethosszig tartó tanulás nem elegendő, kulcskompetenciákra, kompetenciacsomagokra van szükség (Alpek, 2017).

Tudásalapú társadalomban élünk több értelemben is. A tudás generálja a fejlődést, és a munkaerőpiac igénye is nő a magasan képzett munkaerő iránt. Aki korán kiszorul az iskolarendszerből, vagy nem tudja folyamatosan frissíteni ismereteit, könnyen a társadalom peremére szorulhat (Stöckert- Kozák, 2014:16).

A hátrányos helyzetű személyekkel való oktatási célú foglalkozások szerepe egyre inkább felértékelődik. A társadalmi előrejutásban a végzettség és a képzettség meghatározó tényező, azonban a társadalom tagjai nem egyformán képesek ezekhez a lehetőségekhez hozzájutni. Egyes társadalmi csoportok mindenkor természetes módon szerzik meg a szükséges tudást, annak érdekében, hogy lépést tudjanak tartani a fejlődéssel, míg más társadalmi csoportoknak segítségre van szükségük ehhez. Ezen tudáshoz való hozzájutási különbség tartós társadalmi rétegződéshez vezethet, melyet az oktatás és a képzés kiterjesztésével lehet mérsékelni (Farkas, 2013).

Az alacsony iskolai végzettség nem az elsajátított ismeretek ,kis mennyisége” miatt teremt hátrányt, hanem a további ismeretek befogadásához nélkülözhetetlen attitűdökben, a fejlődést megalapozó kommunikációs készségekben mutatkozik meg. Egy munkakör betöltéséhez manapság már nem elegendő a megfelelő végzettség, szakképzettség, gyakorlat, olyan munkaerő iránt van igény, aki képes a megújulásra, gyorsan tud alkalmazkodni, folyamatosan átképezhető, fejleszthető. Olyan dolgozókat keresnek, akik nem csak a szakmájukhoz kapcsolódó tudással rendelkeznek, hanem a hatékony munkavégzéshez szükséges tulajdonságokkal is, mint például jó kommunikációs és problémamegoldó készség, meggyőző érvelés, gyors helyzetfelismerő- képesség, kompromisszumkészség, flexibilitás, mobilitás, teherbírás, streszsztűrés, nyitottság és kreativitás (Farkas, 2013).

\section{A hátrányos helyzetüek esetén a következö elvárások jelentkezhetnek a képzéssel kapcsolatban:}

- Megkülönböztetett bánásmód.

- A személyiség stabilizálásának elérése, fejlesztése.

- Tanulási motiváció, a tanulási készség, kommunikációs készség fejlesztése.

- A munkaköri képesség megnevezése, pályaorientáció.

- A hiányzó alapismeretek pótlása.

- A szükséges szakmai és mentális képességek elsajátítása.

- Nyílt, hozzáférhető, rugalmasan egymásra épülő rendszerek alkalmazása.

- A képzést megelőző és a képzés folyamán szükséges szolgáltatások biztosítása (Halmos, 2005:15).

\section{A felnöttképzés lehetöségei a hátrányok csökkentésben}

A képzési cél:

- A hátrányos helyzet miatt kialakult társadalmi egyenlőtlenségek kiküszöbölése.

- „Megfelelő” munkaerő biztosítása a munkaadók számára.

- Funkciói:

- A munkavállalói kompetencia rés csökkentése.

- Az identitástudat, érdekérvényesítő képesség kialakulásának támogatása.

- A társadalmi hasznosságérzet kialakítása.

- A biztonságérzet támogatása.

- A jövőkép kialakítása (Halmos, 2005:18).

\section{Egész életen át tartó tanulás}

A hátrányos helyzetű csoportok munkaerő-piaci esélyeinek javítása kapcsán fontos beszélni 
az egész életen át tartó tanulásról, mivel az elmúlt években alapvető változások zajlottak le a társadalom és gazdaság, az alkalmazott technológiák, a munkaerőpiac és a szociális szféra területein.

\section{EgÉSZ ÉLETEN ÁT TARTÓ TANULÁS FOGALMA}

Az egész életen át tartó tanulásnak számos fogalma létezik. Az élethosszig tartó tanulás egy összetett fogalom, országonként eltérő meghatározással. Sok európai országban az élethoszszig tartó tanulás és a felnőttképzés szinonimának számít (Óhidy, 2006). Lifelong learning fogalma magába foglalja a formális keretek közötti képzéseket, mint például az iskolai, felsőfokú képzést, felnőttképzést, és a nem formális keretek között folyó egyéni és szociális fejlődést (Colardyn, 2004). Az LLL koncepció azokra a tevékenységekre vonatkozik, amelyeket az emberek egész életük során az ismereteik, készségeik és képességeik fejlesztése érdekében végeznek kompetenciák bizonyos területein, személyes, társadalmi vagy foglalkoztatási motívumok miatt (Colardyn, 2005).

\section{Egész életen át tartó tanulás életkor szerint}

- 0-5 életév között: Ebben az időszakban rengeteget tanulnak a gyerekek, ez alapot biztosít számukra a későbbi tanuláshoz, fejlődéshez. Ekkor elsősorban a szimulációnak van nagy szerepe, mivel a gyerekek lemásolják szüleik, kortársaik és környezetük viselkedését.

- 6-24 életév között: Ebben a korban a tanulás elsősorban az oktatási intézményekben folyik alap, közép és felsőfokú szinteken. Ilyenkor a családnak, a társadalmi szervezeteknek, a vallásnak és a médiának van a legnagyobb szerepe a tanulásban.

- 25-60 életév között: Ez a korosztály főként informális módon tanul a médián keresztül, a munkahelyükön, kollégáiktól, trainingeken. Ezek a felnőttek a tapasztalataikból és a problémáik meg- oldásán keresztül tanulnak, ezért szükségük van az értelem, az adottságok és az integritás folyamatos fejlesztésére.

- 60 évnél idősebb korosztály: A 60 évnél idősebb emberek sokat tanulhatnak az életkorukhoz igazodó tevékenységektől, pl. művészet, zene, sport, kézművesség és szociális munka. A korosztály tagjai közösségi önkéntes munkát is végezhetnek szervezetekben, klubokban és egyesületekben (Laal, 2014).

Az egész életen át tartó tanulás a következő változások miatt válik egyre inkább szükségszerüvé

- Munkaerő-piaci igények megváltozása.

- Változó társadalmi környezet: tudás alapú gazdaság és társadalom (a korábban meghatározó munkaerő, energia, technika mellett/helyett), információs társadalom, valamint nagyon gyorsan változó tudás, ismeretek szükségessége a mindennapok és a munka világában.

\section{Kompetencia, kompetenciamenedzsment}

A munkavállaló akkor válik alkalmassá a munka elvégzésére, ha az ismeretek és a rábízott feladatok összhangban állnak a munkavégző kompetenciáival. Azonban az egyén oldaláról történő megközelítésen belül is találkozhatunk kisebb különbségekkel. A legjelentősebb megkülönböztetési szempont az, hogy vajon ezek a képességek tanulhatóak-e, vagy veleszületettek. A jelenleg domináns irányzat a képességek elsajátíthatóságát hangsúlyozza, míg a tradicionális nézet szerint a képesség nem a befogadóképességtől függ, hanem inkább a munkavállaló hajlandóságától és tehetségétől, amit az adott szituációban kamatoztatni képes (Garavan, 2001).

\section{KOMPETENCIA FOGALMA}

A szakirodalomban számos kompetencia fogalom létezik, mivel a területen számos kutató tevékenykedik, a meghatározások igencsak sokszínűek. Mindebből az is következik, hogy 
minden kutató saját céljainak megfelelő kompetencia definíciót használ, vagy a fogalmi sokszínűséget támogatva, alkot és a saját szempontrendszerének megfelelően csoportosítja, kategorizálja a kompetenciákat (Gyökér, 2010). A kompetencia egyenlő a sikeres alkalmazkodással. Egyben az autonóm személyeknek az a törekvése, hogy a munka és a magánélet világát aktívan befolyásolja (Forgács, 2002). A munka világában a kompetencia fogalma az emberi erőforrás menedzsment valamennyi területén alkalmazható, nevezetesen a munkaköri követelmények meghatározásában, a toborzásban és kiválasztásban, a teljesítmény-értékelésben, az ösztönzés-menedzsmentben, a karrier- és utánpótlás-tervezésben és a személyzetfejlesztésben (Elbert, 2000).

Mivel szerepe van a változásokban és a változások kezelésében, a változásmenedzsmentben is, így tehát a szervezeti stratégia részeként megfogalmazott és annak megvalósításához szükséges kritikus kompetenciák valamennyi emberi erőforrás rendszerben megjelennek (Dobák, 2001).

\section{HeLYZETELEMZÉS ÉS A PROBLÉMA MEGFOGALMAZÁSA}

A következőkben a szakirodalom és a témában készült kutatások alapján helyzetelemzést készítek és megfogalmazom a probléma okait.

\section{Probléma okozatai}

A Február Harmadika kutatócsoport eredményei szerint Magyarországon egy téli napon 14.000 hajléktalan ember van az utcán. A 14.000 hajléktalan ember közül $4.000 \mathrm{em}$ bernek lakhatási támogatásra, 7.000 embernek lakhatási és szociális támogatásra, 700 embernek ápolást, gondozást nyújtó intézményi ellátásra lenne szüksége. A jelenlegi szociális szállásnyújtás valamilyen formája 2.300 ember állapotának felel meg. A hajléktalan emberek, saját bevallásuk szerint, 43\%uk súlyos, krónikus beteg, 39\%-ukat egy éven belül kórházban kellett kezelni (Győri, 2021).
A hajléktalan emberek többségének jelenleg a közfoglalkoztatási programokban van lehetősége dolgozni. A munkáltatók elmondása szerint várnák a munkavégzésre felkészült hajléktalanokat, azonban nem tudják, hogy hol érhetik el őket, és arra sincs pontos módszertani leírás, hogy hogyan kell a már munkaképessé tett személyekkel sikeresen együttműködni. Azonban a munkaadók sok esetben előítélettel fordulnak a hajléktalan emberek felé. A hajléktalan emberek számára a munkavállalás során az egyik legjelentősebb problémát az önálló lakhatás hiánya jelenti. Az önálló lakhatás hiánya már az álláspályázás során gondot jelent. Számos munkáltató hátrányosan megkülönbözteti a hajléktalan embereket, nem ad számunkra munkát. Munka hiányában pedig nem megoldható az önálló lakhatás.

Amennyiben egy hajléktalan embernek sikerül elnyerni egy állást, megfelelő lakhatás hiányában nem tud felkészülni a másnapi munkára (tisztálkodás, pihenés).

Probléma a munkásszállók telítettsége, hiánya, illetve az, hogy sok munkáltató csak abban az esetben ad lehetőséget a munkásszálláson való lakhatásra, amennyiben a jelentkező állandó bejelentett lakcímmel rendelkezik.

Hiányosak a hajléktalan emberek munkavállaláshoz szükséges információi. A hajléktalan emberek többségének nincs információjuk olyan alapvető munkavállaló ismeretekről, mint például szerződéskötés, a bruttó és a nettó fizetés közötti különbség, táppénzre és szabadságra való jogosultság és azok feltételei, az igénybevétel módja, szerződésbontás, panaszkezelés.

Gyakran a kiválasztás módszerei sem elég kidolgozottak. Az esetek többségében a munkáltató és a munkavállaló csak a szerződéskötéskor találkozik, ezért nincs lehetőség a munkavállaló tényleges készségeinek, tudásának felmérésére. Az utóbbi ok miatt előfordulhat, hogy valaki nem a kompetenciáinak legmegfelelőbb munkakörbe kerül, ami jelentősen csökkenti a motivációt. Hiányzik 
a munkavállalással kapcsolatos stresszorok, konfliktusforrások kezelésének lehetősége.

Probléma a jelentős mértékű fluktuáció a hajléktalan munkavállalók körében, elsősorban egészségügyi, valamint munkaszocializációs, motivációs problémák miatt.

Az elhelyezkedésben és munkában maradásban nehézséget okoz a beilleszkedés, emiatt nagymértékű a lemorzsolódás.

Az állások megpályázásában további gondot jelent a hajléktalan emberek számára, az önértékelési problémák, a bizonyítványok elvesztése, a fényképes önéletrajz hiánya. A hajléktalan munkavállalók számára nehézséget okoz az, hogy az első fizetésük megérkezéséig nincs megélhetésük, így sok esetben inkább napi/ heti fizetéses munkát keresnek.

\section{Probléma OKAINAK FELTÁRÁSA}

\section{Következtetések, a probléma okainak összefoglalása}

A kutatások alapján az alapprobléma, hogy a hajléktalan emberek többsége nem rendelkezik állandó munkával. A hajléktalan embe- rek nyílt piaci elhelyezkedését több probléma együttese akadályozza. Az első probléma az, hogy az elöítéletek akadályozzák a hajléktalanok munkába állását, a hajléktalan emberekről kialakult negatív sztereotípiák miatt a munkáltatók nem szívesen alkalmazzák őket. A második probléma a lakhatási körülményekhez kapcsolódik. A hajléktalan emberek elhelyezkedését akadályozza az állandó bejelentett lakhely hiánya, ehhez a problémához elsősorban a családi kapcsolatok megromlása, az egészségügyi és pszichés problémák vezetnek.

A következő problémák az emberi tényezőkhöz kapcsolódnak. Probléma a kompetenciák hiánya. Továbbá probléma lehet a szakmai kompetenciák hiánya, vagy azok megkopása, illetve a társas kompetenciák hiánya is, melyek elengedhetetlenül fontosak lennének a munkába álláshoz- munkában maradáshoz. Az emberi tényezőkhöz kapcsolódik a motiváció hiánya is, ide sok tényező vezethet, többek között az önértékelési problémák is. Az utolsó probléma a jelenlegi programokhoz kapcsolódik, a hajléktalan foglalkoztatási

\section{2. ábra Ishikawa diagram}

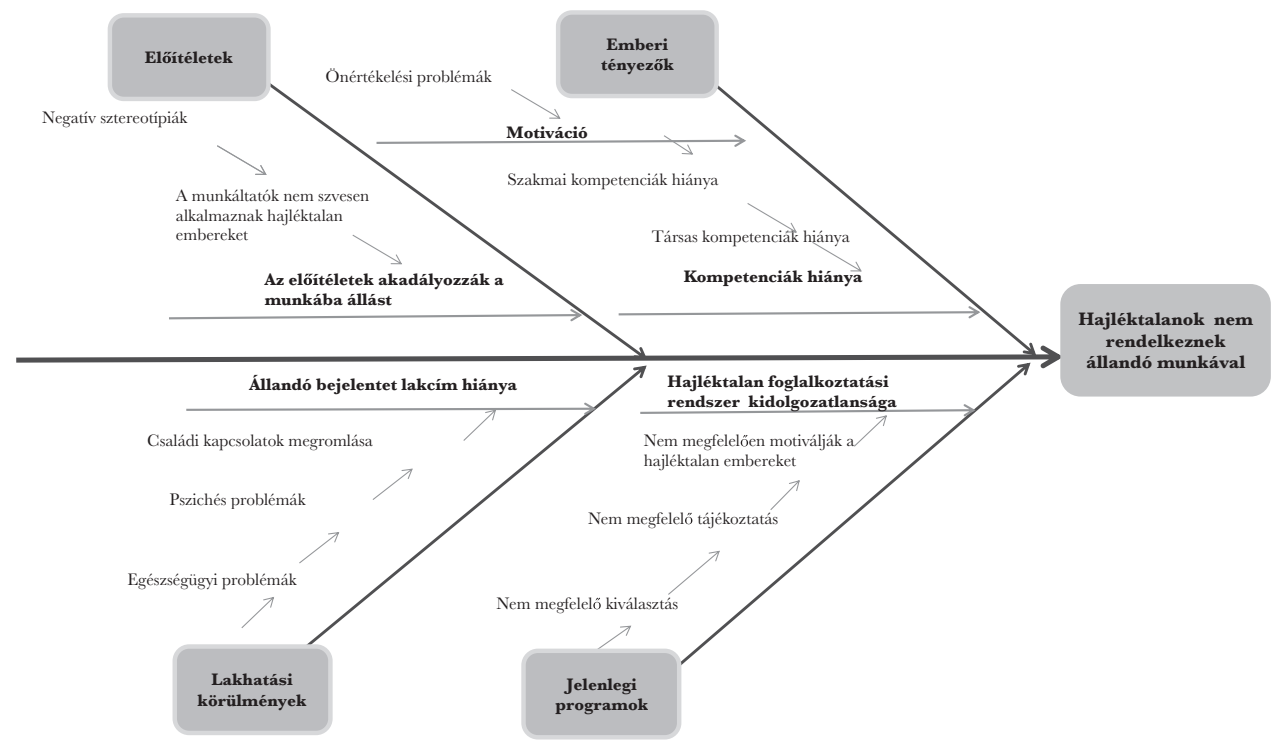

Forrás: Saját szerkesztés 
rendszer jelenleg még nem elég kidolgozott. A hajléktalan embereket gyakran nem megfelelően választják ki az adott munkakör betöltésére, nem megfelelően tájékoztatják őket, illetve a motiválásuk sem megfelelő.

\section{MEgOldÁsi JaVASLATOK}

A hajléktalan emberek elhelyezkedésének egyik fő gátló tényezője az állandó lakhely hiánya.

A nemzetközi gyakorlatok alapján két fö lakhatás-központú megoldást különböztethetünk meg a tartósan közterületeken élők öszszetett szükségletű hajléktalan emberek hatékony kigondozására, a Lépcsőzetes és az Első a lakhatás modellt.

\section{Lépcsözetes modell}

A lépcsőzetes modellben a hajléktalan emberek fokozatosan jutnak el az önálló lakhatáshoz a szociális szolgálatok támogatásával. Az önálló lakóhely ebben az esetben az egyéni problémák (pl. alkoholizmus, viselkedési problémák) megoldásának, az előírt „kezelés” és támogatói programok követésének ,jutalma”.

\section{A modell kritikája}

A modell kritikája szerint az előírt „fejlődési szakaszok" felesleges stresszt okoznak, a program elején a privát szférát és autonómiát minimalizálják, a képességek fejlesztése életszerűtlen módon történik.

Összességében a lépcsőzetes megközelítésmód, mint folyamat évekig eltarthat, nagymértékű lemorzsolódással, a hajléktalan élethelyzet fenntartásával járhat, ha sokan megrekednek a programok legalsó szintjein.

\section{„Housing First” („Elsö a lakhatás”) modell}

Az „Első a lakhatás” modell filozófiája szerint a lakhatás alapvető emberi jog, azt nem kell kiérdemelni az egyéni problémák előzetes megoldásával. Az „Első a lakhatás” programok rögtön önálló lakhatás biztosítására törekednek albérleti szerződésekkel, az általános lakáspiachoz való közvetlen hozzáféréssel és az adott lakóközösségbe történő integrációval. Ez a megoldás is lehetőséget nyújt a szakmai támogatásra, terápiára, mégsem teszi ezeket kötelezővé, és főképpen, nem képezi előfeltételét a lakhatásnak.

\section{3. ábra Housing First és Staircase Modell összehasonlitása}

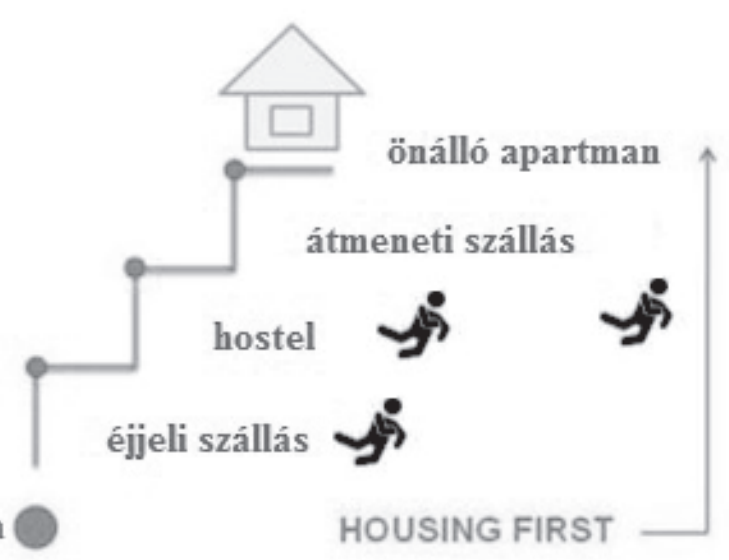

Forrás: Saját szerkesztés 
A program célja a hajléktalan emberek gazdasági és társadalmi integrációjának elősegítése.

Az „Első a lakhatás” modell megközelítése összhangban van az átalakuló nemzetközi szociálpolitikai-jóléti gyakorlattal, amely intézménytelenítésre, decentralizációra és a rászorulók életkörülményeinek normalizációjára (hétköznapivá tételére) törekszik az ellátó helyre összpontosított támogatás helyett az egyénközpontú támogatással (Hannele, 2009).

A támogatás rugalmas, nem ítélkező és nyílt végü, azaz nincs meghatározott határideje. Az „Első a lakhatás” program rendelkezhet célzott, átfogó szolgáltatásokkal, mentálhigiénés dolgozókkal. Léteznek esetmenedzsment alapú „Első a lakhatás” szolgáltatások, ahol a dolgozók fő feladata a külső egészségügyi szolgáltatások koordinálása, szociális munka, intenzív esetkezelési szolgáltatás.

A program segítségével megszerzett munka fontos szerepet játszhat a hajléktalanságból való kilépés megkönnyítésében és fenntartásában.

A kutatási eredmények azt mutatják, hogy az „Első a lakhatás” modell különböző változatai hosszútávon mind eredményesek.

\section{A modell indokoltsága}

Többek között Finnországban is az „Első a lakhatás" modellt alkalmazzák. Finnországban 1997-ben körülbelül 20.000 ember volt hajléktalan, 2008-ra ez a szám 8000-re esett vissza, 2014-ben pedig 8000 alá csökkent ez a tendencia, céljuk a hajléktalanság teljes felszámolása. Ezek alapján elmondható, hogy a modell elősegítheti a hajléktalan emberek elhelyezkedését és munkában maradását.

\section{FELHASZNÁLT IRODALOM}

Alliquander Anna (2013): Hátrányos helyzet, szociális helyzet, munkanélküliek, kisebbségiek. Budapest, SE Népegészségtani Intézet, pp.5-12.

Alpek B. Levente (2017): Hátrányos helyzetü csoportok munkaerópiaci-területi esélyei Magyarországon. Pécs, Pécsi Tudományegyetem, Földtudományok Doktori
Iskola, pp. 5-15.

Andorka Rudolf (2003): Bevezetés a szociológiába. Budapest, Osiris Kiadó. pp.105-115.

Breitner Péter (1999): A hajléktalanná válás lépcsőfokai. Esély, 1999/1 pp.84-104.

Colardyn D. - Bjonavold J. (2004): Validation of Formal, Non-Formal and Informal Learning: Policy and practices in EU Member States,Progress in: European Fournal of Education, Vol.39, pp. 70-81.

Ciserné Adermann Gizella - Fodor Imréné - Koltai Dénes - Kövesi Gusztáv - Kövesi Jenő - Muity György - Nemeskéri Zsolt - Szép Zsófia - Vámosi Tamás - Váradi Ákos (2006): A felnóttek foglalkoztathatóságának növelésére irányuló komplex képzési modellek, különös tekintettel a hátrányos helyzetü csoportokra, javaslatok intézkedésekre. Budapest, Nemzeti Felnőttképzési Intézet, pp.27-32.

Dobák Miklós (2001): Szervezeti formák és vezetés. Budapest, KJK Kerszöv Kiadó, 264p.

Elbert F. Norbert - Karoliny Mártonné - Farkas Ferenc - Poór József (2000): Személyzeti/Emberi eróforrás menedzsment kézikönyv. Budapest, Közgazdasági és Jogi Könyvkiadó, p. 579.

Farkas Éva (2013): A láthatatlan szakma, Tények és tendenciák a felnơttképzés 25 évéról. Pécs, typiART Médiaműhely Kft, pp. 202-210.

Forgács Katalin (2002): Új évezred, „új gazdaság”, új munkaerő? Munkaügyi szemle, 46 évf. 3. szám, pp.910.

Garavan, T.N. - Morley, M. - Gunnigle,P. - Collins, E. (2001): Human capital accumulation: the role of human capital development, Progress in: Fournal of European Industrial Training. Vol.25, pp.48-68.

Gyökér Irén - Finna Henrietta - Krajcsák Zoltán (2010): Emberi eróforrás menedzsment. Budapest BMEGTK Üzleti Tudományok Intézet, pp.87-94.

Halmos Csaba (2005): A felnoottképzésben résztverók elhelyezkedése, különös tekintettel a hátrányos helyzetü rétegekre, régiókra. Budapest, Nemzeti Felnőttképzési Intézet, pp. 15-20.

Hannele Taino - Peter Fedriksson (2009): The Finnish Homelessness Strategy: From a 'Staircase' Model to a 'Housing First' Approach to Tackling Long- Term Homelessness. Pori, Diacornia Univesity of Applied Sciences and Ministry of the Environtment, pp.181-199.

Marjan Laal (2014): Lifelong Learning and Art. ProcediaSocial and Behavioral Sciences, pp. 4047-4051

Nagy Márta (2011): Speciális andragógia. Győr, Szent István Egyetem, pp. 45-48; 80-83.

Óhidy Andrea (2006): Lifelong Learning - az oktatáspolitikai koncepciótól a pedagógiai paradigmáig. $U_{j}$ 
Pedagógiai Szemle, 7-8.

Öry Mária (2005): Hátrányos helyzetü csoportok helyzete a munkaeröpiacon. Budapest, Nemzeti Felnőttképzési Intézet, pp. 20-25.

Stöckert-Kozák Annamária: Élethosszig tartó tanulás, Nem csak tudásátadásról van szó. Új Pedagógiai Szemle, 63. évf. 2. szám, p.16.

Győri Péter - Gurály Zoltán - Szabó Andrea (2021): Világjárvány veszélyében lakástalanul [számítógép-fájl]. URL: https://drive.google.com/file/d/13FhRO_2-CaMdX6_oKHBeNgT2VOSuMBxu/view [2021. augusztus 10.]

Housing First in Finland (2016), [számítógép-fájl]. URL: http://www.housingfirst.fi/en/housing_first/ housing_first_in_finland/housing_first_in_finland [2021. július 20.]

Munkaerőpiaci folyamatok, 2020. I. félév [számítógép-fájl]. URL: https://www.ksh.hu/docs/hun/ xftp/idoszaki/mpf/mpf202/index.html\#cskkentateljestettmunkarkszma [2021. augusztus 16.] 